\title{
Immunohistochemical and electron microscopic findings in benign fibroepithelial vaginal polyps
}

\author{
T P Rollason, P Byrne, A Williams
}

\begin{abstract}
Eleven classic benign "fibroepithelial polyps" of the vagina were examined using a panel of immunocytochemical agents. Two were also examined electron microscopically. In all cases the stellate and multinucleate stromal cells characteristic of these lesions stained strongly for desmin, indicating muscle intermediate filament production. In common with uterine fibroleiomyomata, numerous mast cells were also often seen. Myoglobin staining was negative. Electron microscopical examination confirmed that the stromal cells contained abundant thin filaments with focal densities and also showed the ultrastructural features usually associated with myofibroblasts.

It is concluded that these tumours would be better designated polypoid myofibroblastomas in view of the above findings.
\end{abstract}

Benign vaginal polyps (fibroepithelial polyps, pseudosarcoma botryoides, benign sarcomatous vaginal polyps) can be misdiagnosed as malignant embryonal rhabdomyosarcomas (sarcoma botryoides) though the difference generally in age at which these two tumours occur must make this an uncommon occurrence. ${ }^{1}$ They have received scant attention in the literature and their putative origin from fibroblasts has been generally accepted..$^{1-6}$ They are usually small and asymptomatic but some may present with a mass or bleeding. ${ }^{1}$ This immunohistochemical and electron microscopic study was performed in an attempt to elucidate further the nature of these uncommon lesions.

\footnotetext{
Methods

A systematic review of all vaginal polyps in the files of the Birmingham and Midland Hospital for Women was performed for the years from 1970 to 1988 inclusive. This review yielded 11 "classic" fibroepithelial polyps of the vagina occurring in 10 women aged between 31 and 64. Clinical details were obtained by review of the hospital case notes and by contacting the patients' general practitioners. During the years included in the review about 72000 general gynaecological surgical cases were examined.

\section{LIGHT MICROSCOPY}

Sections were cut from routinely processed, paraffin wax embedded blocks at $4 \mu \mathrm{m}$ and immunocytochemical techniques were performed using a standard peroxidaseantiperoxidase method. ${ }^{7}$ The antibodies used were as follows: polyclonal rabbit antimyoglobin (batch A324, Dako Ltd, High Wycombe, Buckinghamshire), monoclonal anti-desmin (batch M724, Dako Ltd), monoclonal anti-epithelial membrane antigen (batch M613, Dako Ltd), monoclonal anti-vimentin (batch M725, Dako Ltd), polyclonal rabbit anti-cytokeratin (Bio-nuclear services, Reading) and monoclonal anti cytokeratin NCL 5D3 (batch M503, Bio-nuclear services).

Mast cells were shown by a standard chloroacetate esterase method using pararosaniline, ${ }^{8}$ which gave an intense red cytoplasmic colouration, and by the routine toluidine blue method.

An attempt was made to assess semiquantitatively the relative numbers of multinucleate and pleomorphic stromal cells and mast cells present by grading on a scale of $0-+++$. The presence or absence of a more cellular subepithelial dense zone was assessed both on routine haematoxylin and eosin staining and on sections stained with anti-desmin and anti-vimentin. All cases were classified as predominantly myxoid, predominantly collagenous, or mixed (when both patterns were seen in roughly similar proportions). The number of mitotic figures per 10 high power fields was assessed by randomly counting 10 fields on three occasions and averaging the result. For this purpose a wide field microscope was used with a $\times 10$ eyepiece, with a $\times 63$ dry objective, at a final magnification of $\times 630$.

\section{ELECTRON MICROSCOPY}

Blocks were taken from the two most recent cases after routine fixation in neutral buffered formalin, postfixed in one per cent osmium tetroxide for one hour at room temperature, dehydrated in graded alcohols, embedded in Araldite and ultrathin sectioning performed. After staining in uranyl acetate and lead citrate the grids were viewed in a JEOL 100 S electron microscope at $80 \mathrm{Kv}$.

\section{Results}

The clinical details are shown in table 1 . No clear association was seen with parity, hormone treatment etc, though interestingly one patient also had uterine and ileal leiomyomata. No evidence of tumour recurrence or metastasis 
Table 1 Clinical details of investigated cases

\begin{tabular}{|c|c|c|c|c|c|c|}
\hline Case No & Age & Symptoms & Associated pathology & $\begin{array}{l}\text { Follow up } \\
\text { (months) }\end{array}$ & Parity & Site of polyp \\
\hline $\begin{array}{r}1 \\
2 \\
3 \\
4 \\
5 \\
6 \\
7 \\
8 \\
9 \\
10\end{array}$ & $\begin{array}{l}48 \\
41 \\
54 \\
53 \\
52 \\
51 \\
56 \\
31 \\
57 \\
64\end{array}$ & $\begin{array}{l}\text { Polyps catching clothes } \\
\text { Dyspareunia } \\
\text { Swelling and bleeding } \\
\text { None } \\
\text { None } \\
\text { None } \\
\text { None } \\
\text { None } \\
\text { Vaginal swelling } \\
\text { Postmenopausal bleeding }\end{array}$ & $\begin{array}{l}\text { None } \\
\text { None } \\
\text { Leiomyomata of uterus } 10 \text { years previously } \\
\text { Endometrial adenocarcinoma } \\
\text { Leiomyomata of uterus and small bowel } \\
\text { Leiomyomata of uterus } 4 \text { years previously } \\
\text { Breast carcinoma previously } \\
\text { None } \\
\text { None } \\
\text { None }\end{array}$ & $\begin{array}{r}12 \\
12 \\
3 \\
120 \\
132 \\
48 \\
24 \\
120 \\
6 \\
6\end{array}$ & $\begin{array}{l}3+0 \\
3+2 \\
? \\
1+0 \\
2+1 \\
1+0 \\
1+0 \\
0+0 \\
0+0 \\
0+0\end{array}$ & $\begin{array}{l}\text { Right fornix and lower vagina } \\
\text { Posterior wall, near fourchette } \\
\text { Mid-part, anterior wall } \\
\text { Upper third, left side } \\
\text { Anterior wall, mid-third } \\
\text { Anterior wall, lower third } \\
\text { ? } \\
\text { Upper third, right side } \\
\text { Left fornix } \\
\text { Left anterior vaginal wall }\end{array}$ \\
\hline
\end{tabular}

Table 2 Histological findings

\begin{tabular}{|c|c|c|c|c|c|c|c|c|}
\hline Case No & Pattern & $\begin{array}{l}\text { Size } \\
(\mathrm{cm})\end{array}$ & $\begin{array}{l}\text { Mitotic rate } \\
(10 \mathrm{HPF})\end{array}$ & $\begin{array}{l}\text { Subepithelial } \\
\text { dense zone }\end{array}$ & $\begin{array}{l}\text { Mast cell } \\
\text { infiltrate }\end{array}$ & $\begin{array}{l}\text { Pleomorphic } \\
\text { multinucleate cells }\end{array}$ & $\begin{array}{l}\text { Desmin } \\
\text { staining }\end{array}$ & $\begin{array}{l}\text { Vimentin } \\
\text { staining }\end{array}$ \\
\hline $\begin{array}{l}1 \cdot 1 \\
1 \cdot 2 \\
2 \\
3 \\
4 \\
5 \\
6 \\
7 \\
8 \\
9 \\
10\end{array}$ & $\begin{array}{l}2 \\
1 \\
1 \\
2 \\
1 \\
3 \\
1 \\
1 \\
1 \\
1 \\
2\end{array}$ & $\begin{array}{l}1.5 \times 1.0 \\
2.0 \times 1.5 \\
1.0 \times 0.5 \\
2.0 \times 2.0 \\
1.4 \times 0.8 \\
2.5 \times 0.8 \\
1.5 \times 0.8 \\
1.6 \times 0.7 \\
1.2 \mathrm{max} \\
8.0 \times 5.0 \\
2.0 \times 1.5\end{array}$ & $\begin{array}{l}0 \\
0 \\
0 \\
0 \cdot 6 \\
0 \\
0 \\
0 \\
0 \\
0 \\
0 \\
0\end{array}$ & $\begin{array}{l}0 \\
0 \\
2 \\
2 \\
2 \\
2 \\
1 \\
2 \\
2 \\
1 \\
1\end{array}$ & $\begin{array}{l}+ \\
++ \\
+ \\
++ \\
++ \\
+ \\
++ \\
+++ \\
+++ \\
+++ \\
+++\end{array}$ & $\begin{array}{l}++ \\
++ \\
+ \\
+ \\
+ \\
+++ \\
+ \\
++ \\
+ \\
++ \\
+\end{array}$ & $\begin{array}{l}++ \\
+++ \\
++ \\
+++ \\
+++ \\
+++ \\
+++ \\
++ \\
+++ \\
+++ \\
+++\end{array}$ & $\begin{array}{l}++ \\
++ \\
++ \\
+++ \\
+++ \\
+++ \\
++ \\
+++ \\
++ \\
+++ \\
+\end{array}$ \\
\hline
\end{tabular}

Pattern: 1 = myxoid $2=$ collagenous $\begin{aligned} \star_{0} & =\text { absent } \\ 1 & =\text { present on PAP and haematoxylin and eosin staining } \\ 2 & =\text { present on PAP staining alone }\end{aligned}$ was seen in any patient during follow up. No patient later developed a second polyp. The clinical symptoms were variable and inconsistent.

The overall light microscopical findings are summarised in table 2 . The background stromal cells were spindled or stellate with fine collagen bundles between cells clearly defined against a pale background (figs 1 and 2). The cytoplasm of the larger cells was more

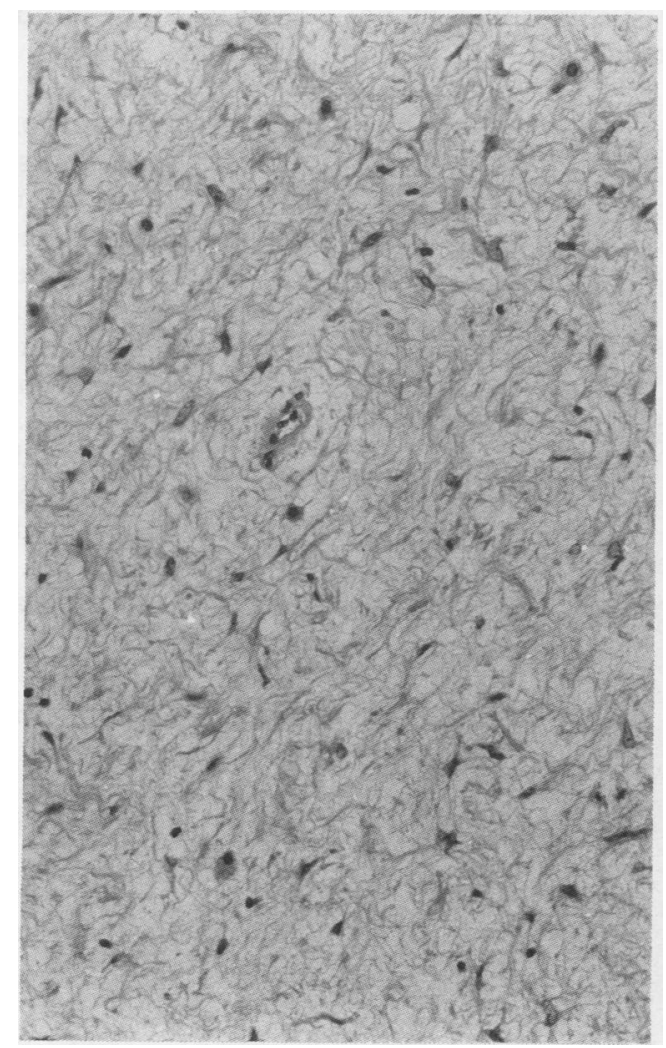

Figure 1 Typical appearances of a fibroepithelial polyp of myxoid pattern with multinucleate cells, poorly defined spindled stromal cells, and a fibrillary, collagenous stroma. (Haematoxylin and eosin.) prominent than the "usual" stellate cells and was eosinophilic and slightly granular. Inflammation was not a striking feature in any of the cases, though this has been stated to be seen in these tumours. Cross striations were not seen.

The cellular pleomorphism classically described in the stromal cells in about $50 \%$ of cases was not, in its more pronounced form, apparent in any of our cases, and the pleomorphism that

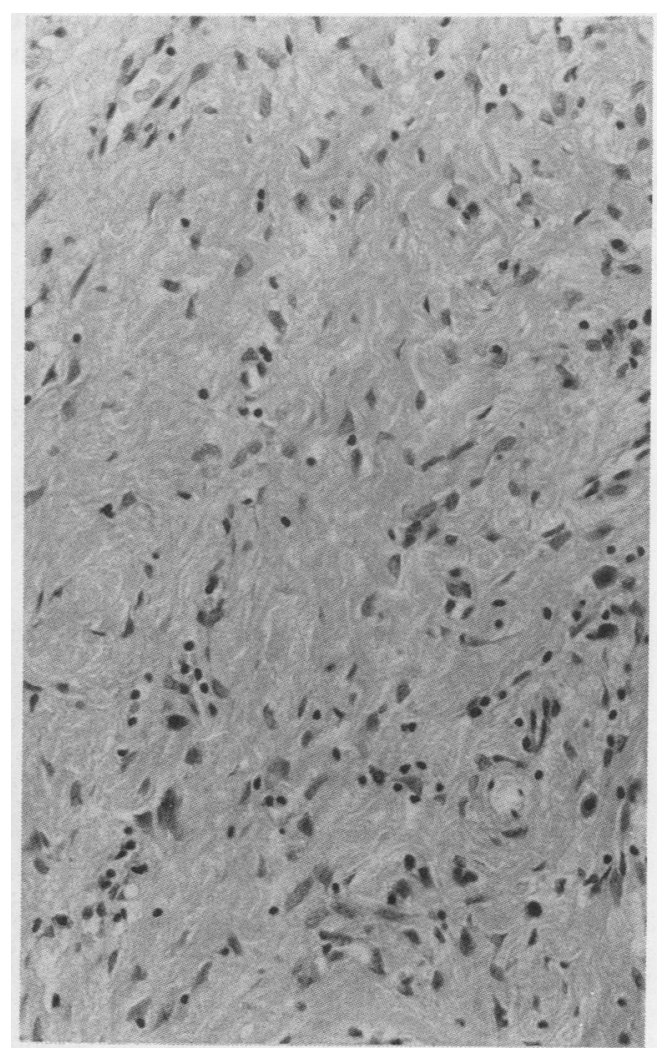

Figure 2 The pattern is that of a fibroepithelial polyp of collagenous type. Compared with that of figure 1, the background is much more collagenous and solid. (Haematoxylin and eosin.) 
Figure 3 Multinucleate cells showing overlapping nuclei against a background of spindle eosin.) cells. (Haematoxylin and

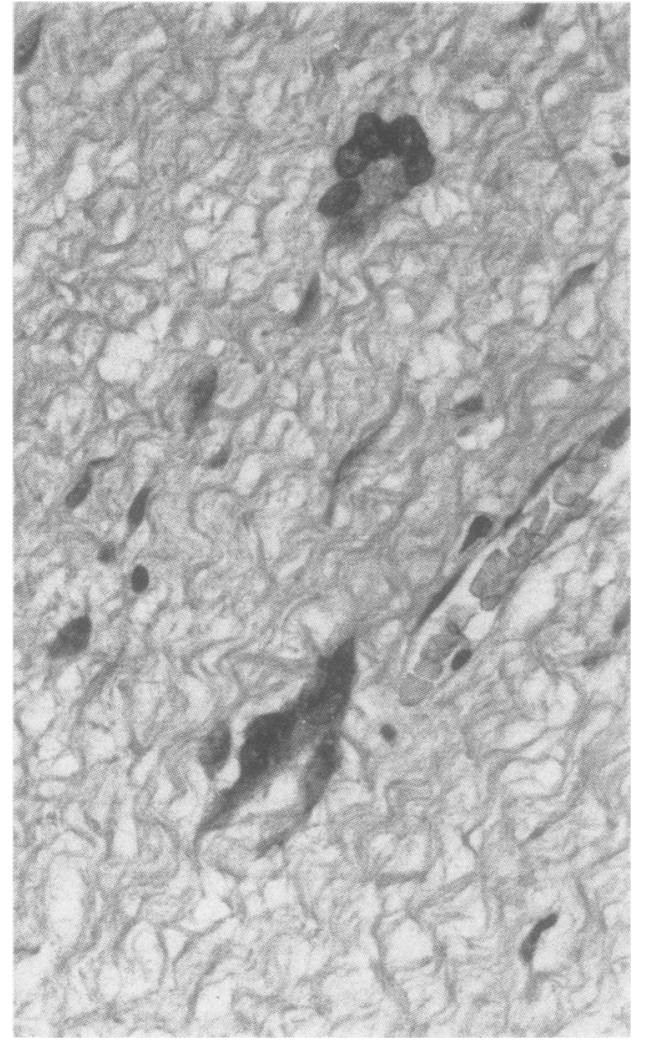

was evident seemed to be mainly due to the difficulty in differentiating in many cells between multinucleation and nuclear atypia. The numbers of clearly multinucleate cells present tended to parallel the numbers of apparently pleomorphic cells. The nuclei of the multinucleate cells were often poorly defined, overlapping, and irregular (fig 3 ). Only very occasional convincingly pleomorphic mononuclear stromal cells were evident.

Figure 4 Intense antidesmin positivity is seen in all stromal cells $(P A P$ method, anti-desmin monoclonal antibody.

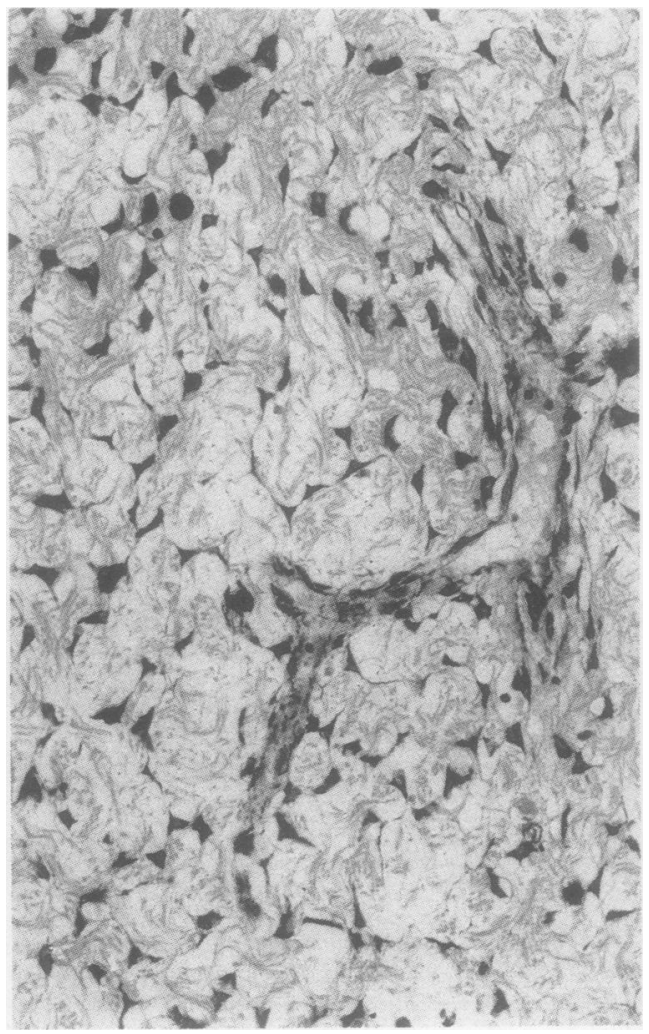

Desmin and vimentin staining were almost always moderately to intensely positive in most or all of the tumour stromal cells (fig 4), with only one exception where vimentin staining was only weakly positive; desmin positivity in this case was, however, intense. Cytokeratin, myoglobin, and epithelial membrane antigen (EMA) staining were invariably absent in stromal cells.

The epithelium of the polyps was entirely squamous and generally showed only slight simple hyperplastic changes; no intraepithelial neoplasia or other clinically important pathology was seen. Slight parakeratosis was evident in a few cases. The stroma of the polyps was notable not only for the loose myxoid appearance in most cases, but also for the profusion of small vessels seen. Only two cases had a predominantly collagenous stroma. The mitotic rate in the tumours was extremely low; only one case showed any stromal cell mitoses.

None of the cases showed the subepithelial "cambium" layer or perivascular cellular sheaths typically associated with embryonal rhabdomyosarcoma, but a feature seen in several cases on simple haematoxylin and eosin staining (fig 5), and evident in all but one case on both vimentin and desmin staining, was the presence of a more compact subepithelial zone which seemed to be both more collagenous and rather more cellular than the centres of the polyps. The nature of this zone could not be further defined and it did not seem to be more mitotically active than the centres of the polyps.

A very striking feature and one not commented on by other workers, was the invariable presence of a stromal mast cell infiltrate which seemed to be diffuse in all cases and very prominent in four.

ELECTRON MICROSCOPY (figs 6 and 7)

In both cases the stromal cells showed clear evidence of smooth muscle differentiation with numerous thin filaments present which showed focal densities. The stromal cell nuclei were folded and invaginated. Rough endoplasmic reticulum and mitochondria were, however, often quite prominent and micropinocytotic vesicles were sparse. The cells were set in a very "loose" background with scattered bundles of mature collagen fibrils present, often closely applied to or within invaginations in the stromal cell bodies. The cells seemed to have either no or a very incomplete external lamina. Subplasmalemmal densities associated with actin filaments were frequently very prominent, and some cells showed focal dilatation of rough endoplasmic reticulum, even occasionally forming large intracellular cystic spaces. The Golgi apparatus was usually not a prominent feature. The above description indicates that the cells showed most of the features typically associated with myofibroblasts. ${ }^{9}$

\section{Discussion}

The cases described in this study all fulfill the histological and clinical criteria for the diag- 


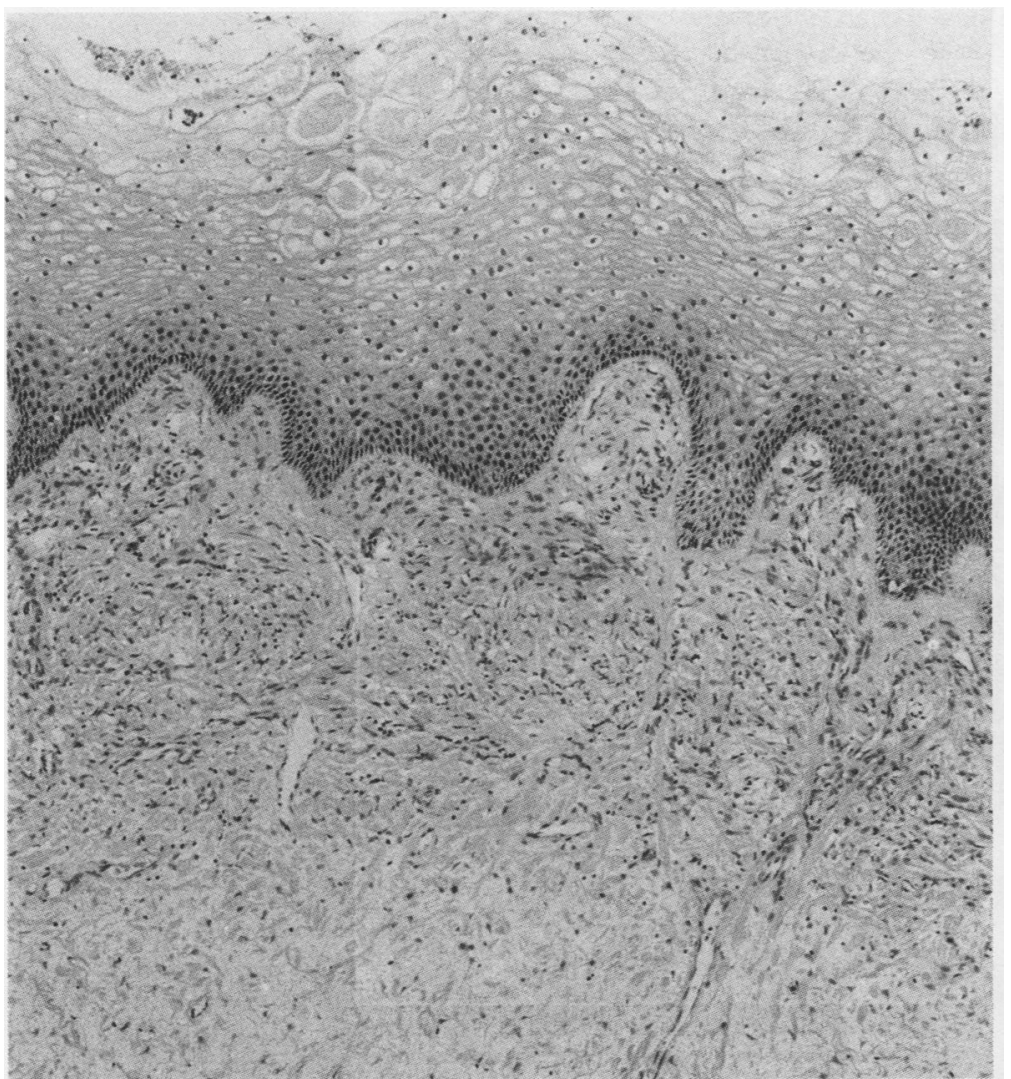

Figure 5 Subepithelial dense zone is seen but no condensation of stroma around vessels is evident. (Haematoxylin and eosin.)

Figure 6 Convoluted pattern of cell nucleus typical of stromal cells. No external cell lamina is visible. nosis of simple fibroepithelial polyps, and this study confirms the entirely benign nature of these tumours. Occasional reported cases have recurred locally, but this was not seen in our series. All but one fell within the usual size range for these tumours previously reported elsewhere, and the unusually large polyp (case 9 , fig 8 ) has been exceeded in size by one

previously reported case, ${ }^{2}$ although this occurred during pregnancy.

On the basis of the immunocytochemical and electron microscopic findings presented together with the tentative support obtained from the mast cell infiltrate, a feature typically seen in uterine leiomyomata, it seems clear that these lesions should no longer be designated fibroepithelial polyps, nor referred to by the nondescript term "vaginal polyp", or worse, the emotive label "pseudosarcoma botryoides". In our opinion as all or almost all of the stromal cells show the features of myofibroblasts, they should preferably be called polypoid myofibroblastomas. This opinion does not, however, concur with that expressed recently by another group ${ }^{6}$ who used electron microscopy and immunocytochemistry and consequently felt that vulval fibroepithelial polyps (which they thought were similar to the vaginal variant) were of fibroblastic origin and showed no desmin staining or electron microscopic smooth muscle features. They also indicated thar in thei: opinion the multinucleate cells present were histiocytic in origin. It is very difficult to explain this difference in findings other than to suggest that the vulval and vaginal polyps are of different pathogenesis: in view of their histological similarity this seems unlikely.

Interestingly, several other reactive and

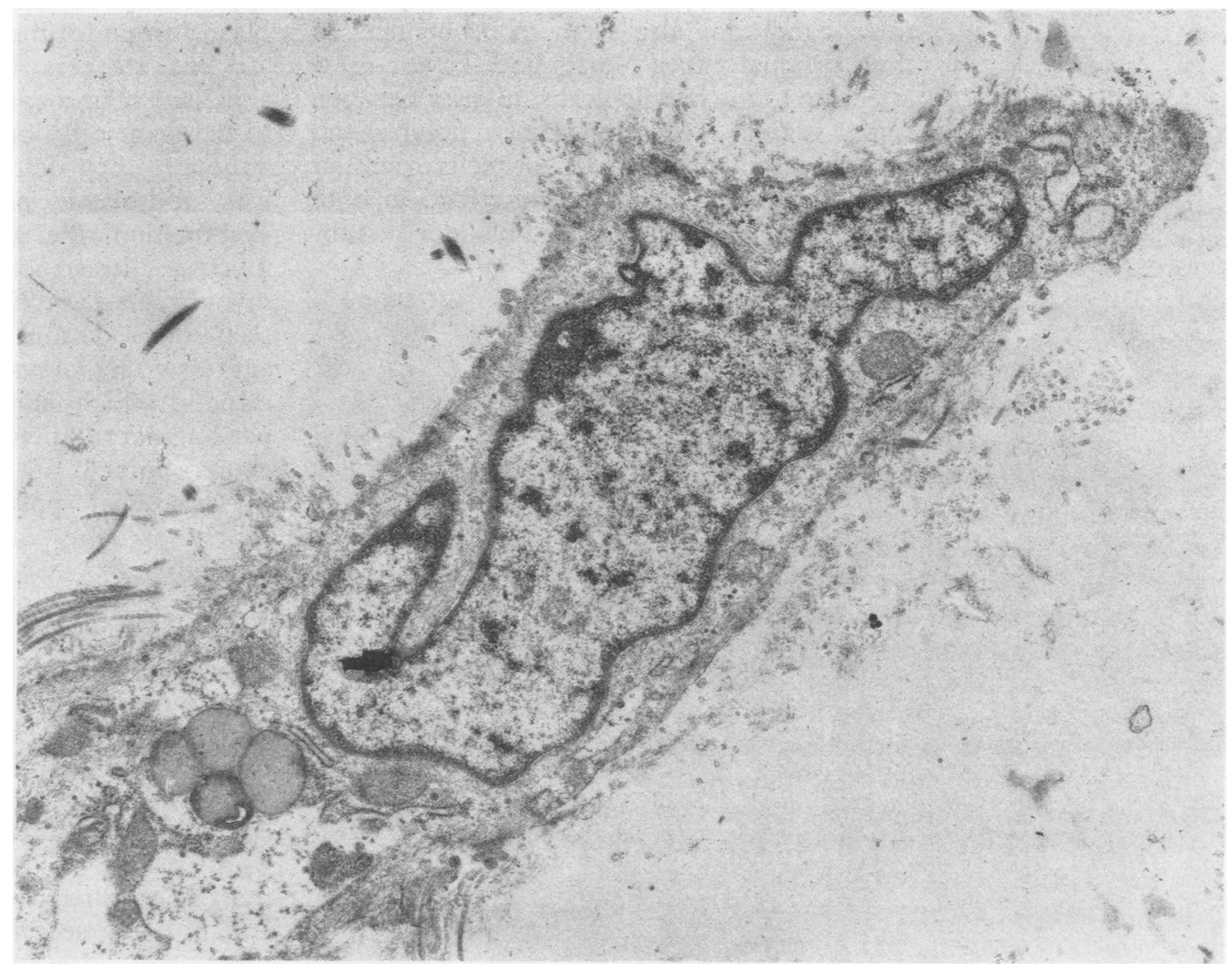
be fibroblastic have been shown to contain myofibroblasts, ${ }^{9}$ and in particular they have been suggested to be the major cell type in another female genital tract benign neoplasmnamely, uterine plexiform tumour-by one group. ${ }^{10}$ The pleomorphic appearance noted in a proportion of vaginal "fibroepithelial" 


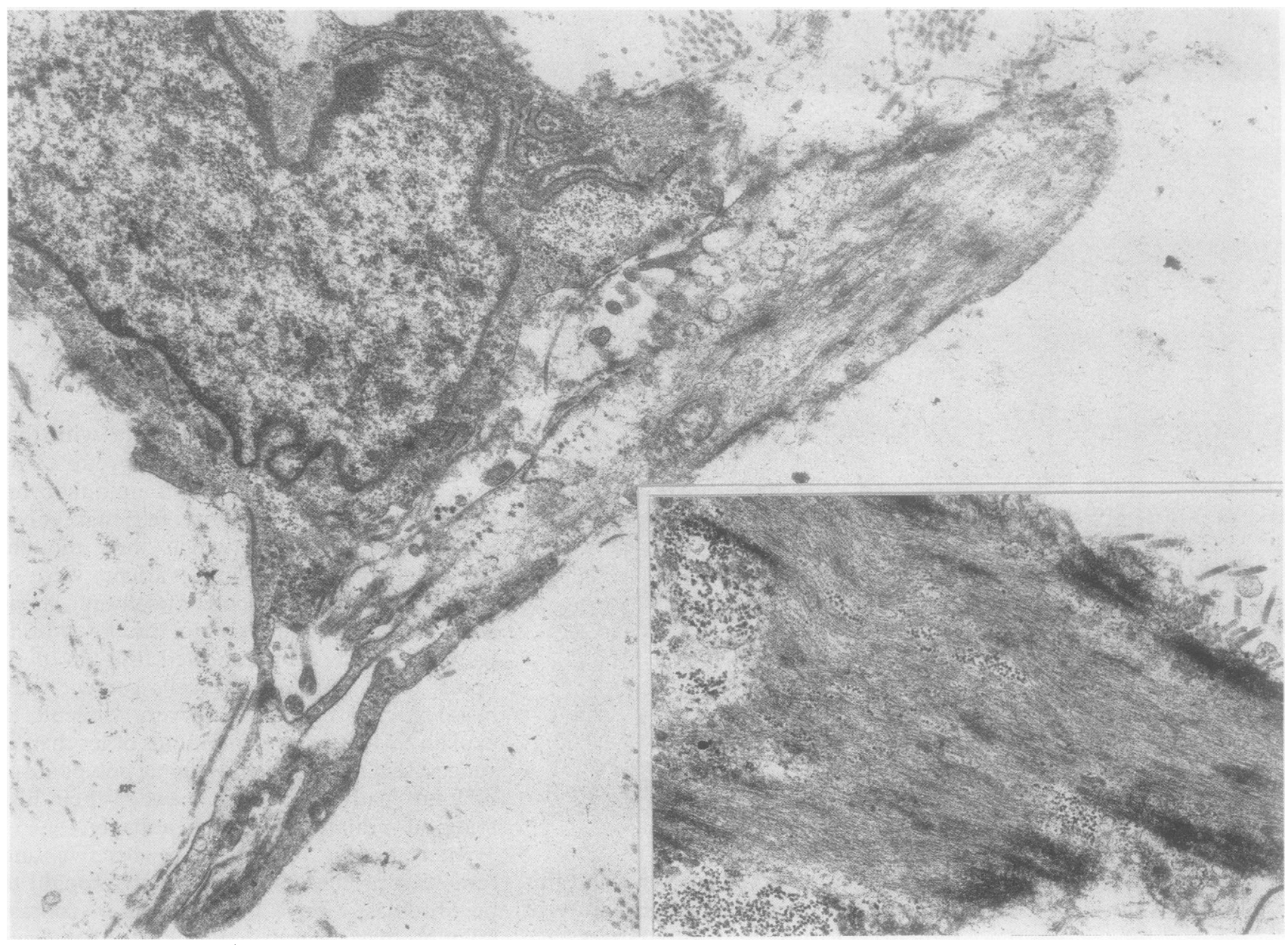

Figure 7 Focal densities on fine filaments, rough endoplasmic reticulum, and a convoluted nucleus are evident in a cell showing no external lamina.

Inset: subplasmalemmal densities are prominent.

polyps is also seen in other conditions, also comprising myofibroblasts-for example, nodular pseudosarcomatous fasciitis, ${ }^{11}$ and these conditions also seem to be benign. In their original paper Norris and Taylor drew attention to the histological similarity between some vaginal "fibroepithelial" polyps and nodular fasciitis. ${ }^{1}$ Multinucleate cells of similar appearance have also been described in both upper respiratory tract ${ }^{1213}$ and bladder ${ }^{1415}$ subunusually large polyp $(8 \times 5 \times 4 \mathrm{~cm})$ shows a frond like surface pattern and no stalk (base at bottom of photograph).

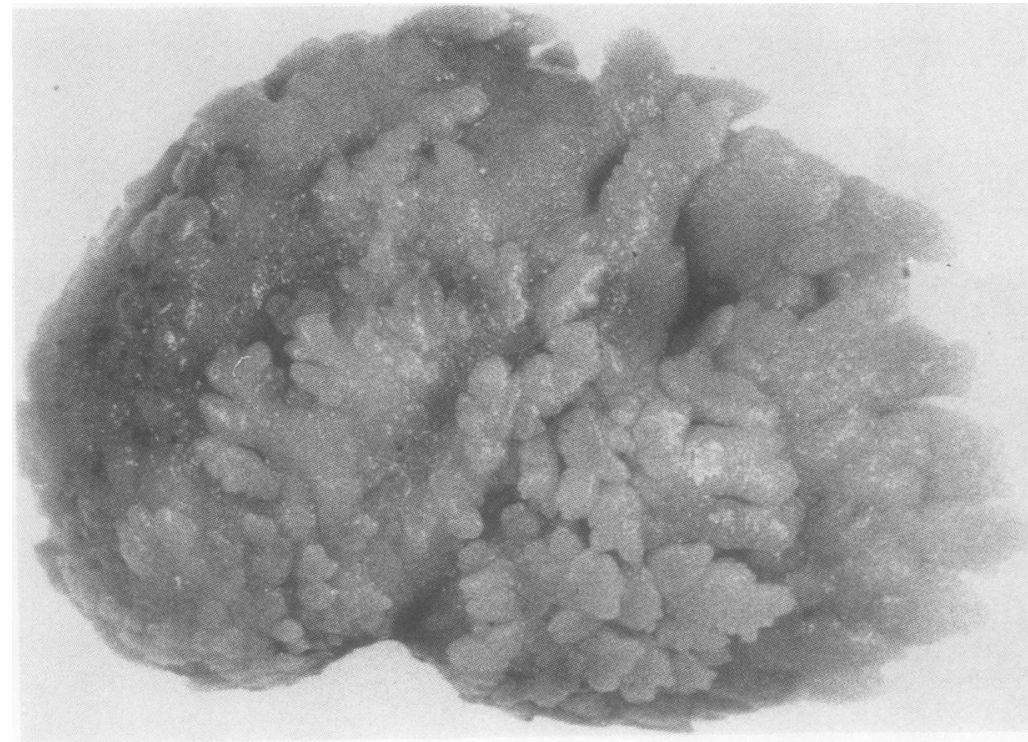

mucosa in inflammatory and reactive conditions, though the electron microscopic appearances favoured a histiocytic or fibroblastic origin for the pleomorphic cells.

Some workers have commented on the similarity of fibroepithelial polyps of the vagina to the giant cell fibroma of oral mucosa, ${ }^{5}$ and although they felt that the vaginal lesion was fibroblastic on electron microscopical examination, the giant cell fibroma of oral mucosa ultrastructurally seems to be of myofibroblast origin. ${ }^{16}$ We have previously seen intense desmin positivity in a single case of aggressive angiomyxoma of the female pelvis, a tumour which shows a predilection for a paravaginal and pelvic site of origin and shows many points of similarity with vaginal fibroepithelial polyps, though its clinical course is one of extensive local tissue infiltration.

Elliot and Elliot have suggested that a subepithelial zone of looser tissue, with occasional pleomorphic cells similar to the appearance of a fibroepithelial polyp, exists normally in the cervix and vagina of a proportion of women. ${ }^{17}$ Clearly, if this is the case then it may provide the site of origin for fibroepithelial polyps. If the cells in this putative zone are also myofibroblasts then it is likely that, as at other sites, they have a contractile and possibly secretory role, maintaining the functional integrity of this organ, the 
physiological functions of which require major expansile capability.

O'Quinn et al have emphasised that a particular hormonal milieu is, in their opinion, likely to be needed to form fibroepithelial polyps, as they may be seen (rarely) at birth or may arise during pregnancy. ${ }^{18}$ Expansion of this hormone sensitive theory to the subepithelial zone described by Elliot and Elliot would clearly be of theoretical interest but is at present entirely speculative. Further studies of the vaginal subepithelial zone are clearly needed to clarify its structure and role.

We thank Mr A Cooper for his excellent photographic assistance and Mrs S Smith for typing the manuscript.

1 Norris HJ, Taylor HB. Polyps of the vagina. A benign lesion resembling sarcoma botryoides. Cancer 1966;19:227-32.

2 Elliot GB, Reynolds HA, Fidler HK. Pseudo-sarcoma botryoides of cervix and vagina in pregnancy. $J$ Obstet botryoides of cervix and vagina in pregnan
Gynaecol $\mathrm{Br}$ Commonwealth 1967;74:728-33.

3 Burt RL, Prichard RW, Kim BOKS. Fibroepithelial polyp of the vagina. A report of five cases. Obstet Gynaecol 1976; 47:525-45.

4 Chirayil SJ, Tobon H. Polyps of the vagina: A clinicopathological study of 18 cases. Cancer 1981;47:2904-7.

5 Miettinen M, Wahlstrom T, Vesterinen E, Saksela E. Vaginal polyps with pseudosarcomatous features. clinicopathologic study of seven cases. Cancer 1983;
6 Ostor AG, Fortune DW, Riley CB. Fibroepithelial polyps with atypical stromal cells [Pseudosarcoma Botryoides] of vulva and vagina: A report of 13 cases. Int J Gynecol Pathol 1988;7:351-60.

7 Sternberger LA, Hardy PHJ, Cuculis JJ, Meyer HG. The unlabelled antibody enzyme method of immunocytochemistry. Preparation and properties of soluble antigenantibody complex [horseradish peroxidase-antihorserish peroxidase] and its use in the idase-antihorseradish peroxidase] and its use in the identification
spirochaetes. J Histochem Cytochem 1970;18:315-33.

8 Maloney WC, McPherson K, Fliegelman L. Esterase activity in leucocytes demonstrated by the use of Napthol AS-D Chloroacetate substrate. J Histochem Cytochem

9 Ghadially FN. Diagnostic electron microscopy of tumours. London: Butterworths, 1985:456.

10 Fisher ER, Paulson JD, Gregorio RM. The myofibroblastic nature of uterine plexiform tumour. Arch Pathol Lab Med 1978;102:477-80.

11 Wirman JA. Nodular fasciitis, a lesion of myofibroblasts. Cancer 1976;38:2378-89.

12 Klenoff BH, Goodman ML. Mesenchymal cell atypicality in inflammatory polyps. J Otol Laryngol 1977;91:751-6.

13 Kindblom L-G, Angervall L. Nasal polyps with atypical stromal cells: a pseudosarcomatous lesion. Acta Pathol Lab Med 1984;92:65-72.

14 Antonakopoulos GN, Newman J. Eosinophilic cystitis with giant cells. A light microscopic and ultrastructural study. Pathol Lab Med 1984;108:728-31.

15 Wells HG. Giant cells in cystitis. Arch Pathol Lab Med 1938;26:32-43.

16 Weathers DR, Campbell WG. Ultrastructure of the giant cell fibroma of the oral mucosa. Oral Surg Pathol Med 1974;38:550-61.

17 Elliot GB, Elliot JDA. Superficial stromal reaction of th. lower female genital tract. Archives of Pathology 1973, 95:100-1.

18 O'Quinn AG, Edwards CL, Gallagher HS. Pseudosarcoma botryoides of the vagina in pregnancy. Gynecol Oncol 1982;13:237-41. 